\title{
The Examination of the Relation between Teacher Candidates' Problem Solving Appraisal and Utilization of Motivated Strategies for Learning
}

\author{
Ozden Turgut $^{1}$, Gurbuz Ocak ${ }^{1}$ \\ ${ }^{1}$ Department of Educational Sciences, Afyon Kocatepe University, Turkey \\ Correspondence: Ozden Turgut, Department of Educational Sciences, Afyon Kocatepe University, Turkey.
}

Received: July 24, 2017 Accepted: August 29, $2017 \quad$ Online Published: September 10, 2017

doi:10.11114/jets.v5i10.2550 URL: https://doi.org/10.11114/jets.v5i10.2550

\begin{abstract}
This study examines the relation between teacher candidates' problem solving appraisal and utilization of motivated strategies for learning. The study has been carried out with 416 teacher candidates. A correlation has been used between problem solving appraisal and utilization of motivated strategies for learning. Besides, regression analysis has been used to find out whether problem solving appraisal predicts utilization of motivated strategies for learning. In addition, it has been questioned whether various variables (gender, department, class level) and problem solving appraisal have a common effect on utilization of motivated strategies for learning. Results indicate that for both women and men, there is a significant and negative sided relationship between problem solving appraisal and utilization of motivated strategies for learning. Besides, except Elementary Science Education and Early Childhood Education departments, for all the departments, there is a significant relationship between problem solving appraisal and utilization of motivated strategies. Finally, it has been found that problem solving appraisal predicts utilization of motivated strategies significantly, but there is not a common effect of problem solving appraisal and various variables (gender, department, class level) on utilization of motivated strategies for learning.
\end{abstract}

Keywords: utilization of motivated strategies for learning, problem solving appraisal, teacher candidates

\section{Introduction}

Learning is the main goal of all the education stages. For this reason, it is compulsory to examine the factors that support learning. One of the main factors that effective on the level of learning of individuals is motivation level. Motivation is one of the necessary prerequisites for learning. Individuals generally rapidly learn the matters which they have interest and curiosity for (Selçuk, 2012). It is very unfeasible for the individual to learn, when the individual does not have an interest. The individuals that have no motivation do not perceive a linkage between their own behaviors and the outcomes of their behaviors; for this reason, they do think that they have not the control (Deci \& Ryan, 1991; as cited in Baker, 2003). Consequently, it can be seen that there is a relation between the motivation and intentional behaviors of an individual.

There is a necessity of motivation for the students to augment their level of learning. But it seems that this cannot be actualized automatically. For this reason, it can be said that the students should use various tactics and strategies. For instance, certain strategies like repeating for bringing back the information facilitate arriving specific learning goals. Corno (1993) has put motivation control strategies and emotion control strategies forth additionally. These two types of strategies ensure for the students to go on studying and utilize their own resources (As cited in Butler, 1995). Dembo and Eaton (1997) remarked that individuals use the strategies, such as self-talk, goal-setting, concentration and attention, time-management, for their own motivation in school. Zimmerman and Risemberg (1997) underlined the importance of the clearness of goal besides goal-setting. Additionally, they stated that the students who give award or punishment to themselves arrive higher success than the students that do not give. Such an attitude, according to Pintrich (2004), belongs to self-regulative perspective. Self-regulative perspective assumes that individuals can follow, control and regulate their own cognitions, motivation and behaviors. These motivational self-regulation strategies includes the attempts of the individual to control his/her own self-efficacy by positive self-talk. But Pintrich (2004) stated that this is not an available regulation everytime and in every milieu, but only for certain conditions. The students that have the self-regulative perspective take the responsibility on their learning processes by thinking about their studies and making regulations under the light of feedbacks (Zimmerman, 2008; as cited in Brown, Peterson \& Yao, 2016). Besides that, 
learning motivation is appreciated as a very important internal resource for effective self-regulatory learning (Boekaerts, 1999; as cited in Engelschalk, Steuer \& Dresel, 2016). The close relationship and also the difference between motivation and self-regulation processes can be summarized as the following: While motivation stimulates the formation of the decisions towards going into action and moving ahead, self-regulating processes stimulate specific and intentional actions for preserving these decisions (McMahon \& Luca, 2001; as cited in Bruso \& Stefaniak, 2016). Therefore, academic self-regulation is the concept for defining the proactive efforts of the individuals for regulating their own academic learning and performances in a metacognitive manner (Zimmerman, 1986; as cited in Zimmerman \& Martinez-Pons, 1992). The students that have self-regulatory skills use more strategies and perceive higher self-efficacy (Zimmerman, 1990; as cited in Bozpolat, 2016).

One of the major issues of individuals that they need self-regulating is, what sort of an attitude they will point against the problems they face. Studies show that the individuals perceiving themselves as effective problem solvers have a higher tendency to enjoy being in cognitive activity; on the contrary, the individuals perceiving themselves as ineffective problem solvers focus at the problem poorly and have a tendency to accuse themselves (Heppner, Reeder \& Larson, 1983). The way an individual appreciates and perceives their own problem solving skills can be an important component of the approach against the difficulties of life (Heppner, Witty \& Dixon, 2004). Setting forth that individuals perceiving themselves as effective problem solvers are really more effective problem solvers (Heppner, Witty \& Dixon, 2004), it can be proposed that the perception of the individual about their problem-solving skills is important besides the actual problem-solving skills.

Any event an individual is facing can be perceived as a problem. Problem solving is the effort for taking away the difficulties being faced and eliminating the glooms. Solving any problem necessitates a cognitive process (Gelbal, 1991). If an individual cannot motivate themselves, they cannot use the cognitive and metacognitive strategies properly (Şenler, 2011). Studies have shown that the way an individual sees a problem and the degree they perceive themselves efficient are influential on the outcomes; that the individuals relying more on their own skills are more effective problem solvers (Bloom \& Broder, 1950; as cited in Heppner, 1978). Consequently, it can be estimated that the individuals supporting their self-efficacy with their own self-talks are better problem solvers. Additionally, it has been shown that successful problem solvers use more strategies for controlling their behaviors (Heffernan \& Richards, 1981; as cited in Heppner \& Petersen, 1982). On the other hand, less successful problem solvers rely on themselves less against the problems they face (Bloom \& Broder, 1950; as cited in D'Zurilla \& Goldfried, 1971). The opinions of the individuals about themselves on coping against the problems they face are important, because the opinions of the individuals towards the difficulty they are in seem to effect the degree of their coping considerably (Lefcourt, 1966; as cited in D'Zurilla \& Goldfried, 1971).

Strategic planning binds the cognitive and motivational area, according to Covington (1998). In other words, there is a very functional link between our opinions and feelings related to being able to be determinant against the situations we face. D'Zurilla and Goldfried (1971) indicate that the expectancy of the individual about being able to control their domain really elevates the probability of responding effectively.

Multiple methods have been developed about supporting individuals concerning their learning and this continues. Considering this situation shows the effort of the teacher, the effort of the studying individual is also an important indicator for learning. Such that, for an individual that has not decided to learn, it is a very hard issue to set forth a method for transferring a unit of information.

Therefore, it is a necessity for the individual to decide learning and make an effort for learning to take place. The resource of strength for the individual to make them active is their motivation. If an individual has been motivated, he/she acts and makes use of his energy. It is not easy for every individual and for every situation to begin acting to learn. One of the main characteristics that differentiate the successful and unsuccessful students is having an attitude that is concreting with several behaviors, such as being active to learn, relating the new information with the old, specifying aim for himself/herself and asking for help when necessary (Turan \& Demirel, 2010; as cited in Bozpolat, 2016). Zimmerman (1990) suggested that motivation and learning are interrelated processes and the indiivduals that are highly self-regulating are more proactive about their own learning (Littlejohn, Hood, Milligan \& Mustain, 2016).

It may be necessary for the individual to utilize various motivational strategies for taking action to learn. These strategies can be exemplified as the self-talk telling the individual that he/she is competent and rewarding oneself for the effort made. For instance, self-regulating students go on studying determinedly till they become successful (Kizilcec, Perez-Sanagustin \& Maldonado, 2017). Therefore, the individual making effort for taking action intentionally carries also out a cognitive activity. Could any linkage be between this activity and the individual's problem solving appraisal? When the finding stating that high level test anxiety is related with the decrease of self-confidence and personal control feeling (Blankstein, Flett \& Batten, 1989; as cited in Heppner, Witty \& Dixon, 2004) is considered, is problem solving 
appraisal stimulating or inhibiting the individual taking action for learning? If the individual is looking for and finding the appropriate strategy to begin for acting himself/herself, how determinative is his/her opinion about his/her problem solving appraisal about the problems he/she has faced thereat? Finding an answer to this question can set forth the necessity for the individuals to utilize motivated strategies for studying more effectively by enhancing their problem solving skills.

For this reason, the question whether there is a relation between an individual's utilization of motivated strategies for learning and his/her problem solving appraisal has been the starting point of this study.

The Problem: Is there a significant relationship between teacher candidates' problem solving appraisal and utilization of motivated strategies for learning?

The Sub-problems:

1) Is there a significant relationship between teacher candidates' level of problem solving appraisal and utilization of motivated strategies for learning?

2) Is there a significant relationship between teacher candidates' level of problem solving appraisal and utilization of motivated strategies for learning in terms of gender?

3) Is there a significant relationship between teacher candidates' level of problem solving appraisal and utilization of motivated strategies for learning in terms of department?

4) Is there a significant relationship between teacher candidates' level of problem solving appraisal and utilization of motivated strategies for learning in terms of class level?

5) Does teacher candidates' level of problem solving appraisal predict their utilization of motivated strategies for learning?

6) Do teacher candidates' level of problem solving appraisal and other various variables (gender, department, class level) have a common effect on their utilization of motivated strategies for learning?

\section{Method}

\subsection{Model of the Research}

This research examining teacher candidates' utilization of motivated strategies for learning in terms of their problem solving appraisal has been carried out with relational screening model. Relational screening model has been preferred because it screens whether there is a covariation between two or more variables (Karasar, 2010). The two variables of this research that whether there is a relation is being examined are teacher candidates' utilization of motivated strategies for learning and their problem solving appraisal.

\subsection{Population and Sample}

For the purpose of examining teacher candidates' utilization of motivated strategies for learning in terms of problem solving appraisal, 2637 teacher candidates that are studying in the $1^{\text {st }}, 2^{\text {nd }}, 3^{\text {rd }}$ and $4^{\text {th }}$ class levels of Afyon Kocatepe University Faculty of Education constitutes the study population of the research. While sampling is determined, stratified purposive sampling has been preferred. Stratified purposive sampling has been preferred because it ensures representing, descripting and making comparisons between specific sub-groups (Büyüköztürk, Kılıç-Çakmak, Akgün, Karadeniz \& Demirel, 2011). In this research, the numbers of the male and female students have been learned from the bureau of student affairs and as a result, sampling has been run according to this proportion.

The sample of this research consists of 416 teacher candidates, including 123 male and 293 female students. For the details of the sample, see Table 1. 
Table 1. Sample distribution

\begin{tabular}{|c|c|c|c|}
\hline Variable & Value & $\mathbf{f}$ & $\%$ \\
\hline \multirow{3}{*}{ Gender } & Female & 293 & 70.4 \\
\hline & Male & 123 & 29.6 \\
\hline & Total & 416 & 100 \\
\hline \multirow{8}{*}{ Department } & Elementary & 87 & 20.9 \\
\hline & Education & & \\
\hline & Social Studies Education & 74 & 17.8 \\
\hline & Early Childhood Education & 104 & 25.0 \\
\hline & Primary Education & 44 & 10.6 \\
\hline & Turkish Language Education & 67 & 16.1 \\
\hline & Elementary Math Education & 40 & 9.6 \\
\hline & Total & 416 & 100 \\
\hline \multirow{5}{*}{ Class level } & $1^{\text {st }}$ class & 51 & 12.3 \\
\hline & $2^{\text {nd }}$ class & 84 & 20.2 \\
\hline & $3^{\text {rd }}$ class & 180 & 43.3 \\
\hline & $4^{\text {th }}$ class & 101 & 24.3 \\
\hline & Total & 416 & 100 \\
\hline
\end{tabular}

2.3 Data Collection and Analysis

The research is based on the data gathered by two scales. The scales that are responded by 416 teacher candidates have been analysed. First of all, normal distribution of the data based on the basic variables of the study, problem solving appraisal and the utilization of motivated strategies for learning is checked. By controlling the proportion of the skewness value to its own standart error (Can, 2013), it is concluded that the data is distributed normally. To apprehend whether there is a significant relationship between teacher candidates' problem solving appraisal and their utilization of motivated strategies for learning in terms of gender, department and class level, simple correlation analysis has been used. Then, to apprehend whether teacher candidates' utilization of motivated strategies is predicted by their problem solving appraisal, simple regression analysis has been used. Finally, to apprehend whether teacher candidates' problem solving appraisal and various variables (gender, department, class level) have a common effect on the utilization of motivated strategies, two-way anova has been used.

\subsection{Data Collection Instruments}

\section{The Motivated Strategies for Learning Questionnaire}

The Motivated Strategies for Learning Questionnaire (Pintrich, Smith, Garcia, \& McKeachie, 1993) consists of two sections, named as "Motivation" and "Learning Strategies". The instrument consists of 34 items that are grouped under subgroups of motivation section as task value, test anxiety and control of learning beliefs; and under subgroups of learning strategies section as metacognitive self-regulation, effort regulation and peer learning. It is a self-report questionnaire, on a 7-point likert-type scale ( $1=$ not at all true of me to $7=$ very true of me). The scale has been translated and adapted into Turkish by Sungur (2004). The Cronbach alphas of the adaptation study have been respectively, task value .87 , test anxiety .62 , control of learning beliefs .62, metacognitive self-regulation .81 , effort regulation .62 and peer learning .61 (As cited in Şenler, 2011). The Cronbach alphas of the current study are respectively, task value .81, test anxiety .60 , control of learning beliefs .57 , metacognitive self-regulation .76 , effort regulation .43 and peer learning .54. The Cronbach alpha of the whole items has been calculated as .87.

\section{The Problem Solving Inventory}

The Problem Solving Inventory (Heppner \& Petersen, 1982) is an instrument to measure the problem solving appraisal of individuals. This inventory assesses the evaluation of the individual's perception of his/her own problem solving beliefs and styles, not his/her actual problem solving skills (Heppner, Witty \& Dixon, 2004). The adaptation study of the inventory to Turkish language has been carried out by Şahin, Şahin \& Heppner (1993). The inventory consists of 35 items and the responses to the items range between 1 (strongly agree) to 6 (strongly disagree). The inventory has six sub-groups for problem solving approaches: Impulsive, reflective, problem solving confidence, avoidant, monitoring and playfulness. The Cronbach alpha coefficient of the inventory was .88 by Şahin, Şahin \& Heppner (1993) and .84 by Ocak \& Eğmir (2014). The coefficient calculated by the data of this study has been .87 .

\section{The personal information form}

The personal information form has been designed by the researchers for gathering the demographic information of the participants. The form has provided the information about the gender, department and class level of the participant students. 


\section{Findings}

The findings that are related to the sub-problems are presented below.

$\mathbf{1}^{\text {st }}$ Sub-problem: Is there a significant relationship between teacher candidates' level of problem solving appraisal and utilization of motivated strategies for learning?

As the result of the simple correlation analysis, it has been found that there is a significant and a negative-sided relationship between teacher candidates' problem solving appraisal and their utilization of motivated strategies for learning $(\mathrm{r}=-.262, \mathrm{p}<.01)$. The findings related to the first sub-problem are given in Table 2.

Table 2. The relationship between teacher candidates' problem solving appraisal and their utilization of motivated strategies for learning

\begin{tabular}{|c|c|c|c|}
\hline & & Problem solving appraisal & Utilization of motivated strategies \\
\hline \multirow[t]{3}{*}{ Problem solving appraisal } & $\mathrm{r}$ & 1 & $-.262 * *$ \\
\hline & $\mathrm{p}$ & & .000 \\
\hline & $\mathrm{N}$ & 416 & 416 \\
\hline \multirow{3}{*}{$\begin{array}{l}\text { Utilization of motivated } \\
\text { strategies }\end{array}$} & $\mathrm{r}$ & $-.262 * *$ & 1 \\
\hline & $\mathrm{p}$ & .000 & \\
\hline & $\mathrm{N}$ & 416 & 416 \\
\hline
\end{tabular}

$* * \overline{\mathrm{p}<.01}$

$2^{\text {nd }}$ Sub-problem: Is there a significant relationship between teacher candidates' level of problem solving appraisal and utilization of motivated strategies for learning in terms of gender?

As the result of the simple correlation analysis, it has been found that there is a moderate and significant, but a negative-sided relationship between female teacher candidates' problem solving appraisal and their utilization of motivated strategies for learning $(\mathrm{r}=-.270, \mathrm{p}<.01)$. Besides, it has also been found that there is a moderate and significant, but a negative-sided relationship between male teacher candidates' problem solving appraisal and their utilization of motivated strategies for learning $(\mathrm{r}=-.250, \mathrm{p}<.01)$. The findings related to the second sub-problem are given in Table 3.

Table 3. The relationship between teacher candidates' problem solving appraisal and their utilization of motivated strategies for learning in terms of gender

\begin{tabular}{lccccc}
\hline Gender & & & & Problem solving appraisal & \\
& & & $\mathrm{r}$ & $\mathrm{N}$ & \\
\multirow{2}{*}{ Male } & $\begin{array}{c}\text { Utilization of } \\
\text { motivated } \\
\text { strategies }\end{array}$ & $\mathrm{r}$ & $-.250^{* *}$ & & \\
& $\mathrm{~N}$ & $\mathrm{p}$ & & \\
\hline \multirow{2}{*}{ Female } & Utilization of & $\mathrm{r}$ & $-.270^{* *}$ & & \\
& $\begin{array}{c}\text { motivated } \\
\text { strategies }\end{array}$ & $\mathrm{N}$ & & 293 & \\
\hline 0.01 & $\mathrm{p}$ & & & 0.01 \\
\hline
\end{tabular}

$* * \mathrm{p}<0.01$

$3^{\text {rd }}$ Sub-problem: Is there a significant relationship between teacher candidates' level of problem solving appraisal and utilization of motivated strategies for learning in terms of department?

As the result of the simple correlation analysis, it has been found that there is a significant relationship between the problem solving appraisal and the utilization of motivated strategies for learning of teacher candidates of all the departments data gathered, except Elementary Science Education and Early Childhood Education. While there has been no significant relationship between the problem solving appraisal and utilization of motivated strategies for learning of the teacher candidates of Elementary Science Education $(r=-.193, \mathrm{p}>.05)$ and teacher candidates of Early Childhood Education $(\mathrm{r}=-.148, \mathrm{p}>.05)$, there is a significant relationship between the problem solving appraisal and the utilization of motivated strategies of teacher candidates that are studying up on Social Studies Education $(r=-.243, p$ $<.05)$, Primary Education $(r=-.387, \mathrm{p}<.01)$, Turkish Language Education $(r=-.399, \mathrm{p}<.01)$ and Elementary Math Education $(\mathrm{r}=-.376, \mathrm{p}<.05)$. The findings related to the third sub-problem are given in Table 4. 
Table 4. The relationship between teacher candidates' problem solving appraisal and their utilization of motivated strategies for learning in terms of department

\begin{tabular}{|c|c|c|c|c|c|}
\hline \multirow[t]{2}{*}{ Department } & & \multicolumn{4}{|c|}{ Problem solving appraisal } \\
\hline & & & $\mathrm{r}$ & $\mathrm{N}$ & $\mathrm{p}$ \\
\hline \multirow{3}{*}{$\begin{array}{l}\text { Elementary } \\
\text { Sci. Edu. }\end{array}$} & \multirow{3}{*}{$\begin{array}{c}\text { Utilization of } \\
\text { motivated } \\
\text { strategies }\end{array}$} & $\mathrm{r}$ & -.193 & & \\
\hline & & $\mathrm{N}$ & & 87 & \\
\hline & & $\mathrm{p}$ & & & .073 \\
\hline \multirow{3}{*}{$\begin{array}{l}\text { Social Studies } \\
\text { Edu. }\end{array}$} & \multirow{3}{*}{$\begin{array}{c}\text { Utilization of } \\
\text { motivated } \\
\text { strategies }\end{array}$} & $\mathrm{r}$ & $-.243^{*}$ & & \\
\hline & & $\mathrm{N}$ & & 74 & \\
\hline & & $\mathrm{p}$ & & & .037 \\
\hline \multirow{3}{*}{$\begin{array}{c}\text { Early } \\
\text { Childhood } \\
\text { Edu. }\end{array}$} & \multirow{3}{*}{$\begin{array}{c}\text { Utilization of } \\
\text { motivated } \\
\text { strategies }\end{array}$} & $\mathrm{r}$ & -.148 & & \\
\hline & & $\mathrm{N}$ & & 104 & \\
\hline & & $\mathrm{p}$ & & & .134 \\
\hline \multirow{3}{*}{ Primary Edu. } & \multirow{3}{*}{$\begin{array}{c}\text { Utilization of } \\
\text { motivated } \\
\text { strategies }\end{array}$} & $\mathrm{r}$ & $-.387 * *$ & & \\
\hline & & $\mathrm{N}$ & & 44 & \\
\hline & & $\mathrm{p}$ & & & .009 \\
\hline \multirow{3}{*}{$\begin{array}{l}\text { Turkish Lang. } \\
\text { Edu. }\end{array}$} & \multirow{3}{*}{$\begin{array}{c}\text { Utilization of } \\
\text { motivated } \\
\text { strategies }\end{array}$} & $\mathrm{r}$ & $-.399 * *$ & & \\
\hline & & $\mathrm{N}$ & & 67 & \\
\hline & & $\mathrm{p}$ & & & .001 \\
\hline \multirow{3}{*}{$\begin{array}{l}\text { Elementary } \\
\text { Math. Edu. }\end{array}$} & \multirow{3}{*}{$\begin{array}{c}\text { Utilization of } \\
\text { motivated } \\
\text { strategies }\end{array}$} & $\mathrm{r}$ & $-.376^{*}$ & & \\
\hline & & $\mathrm{N}$ & & 40 & \\
\hline & & $\mathrm{p}$ & & & .017 \\
\hline
\end{tabular}

$4^{\text {th }}$ Sub-problem: Is there a significant relationship between teacher candidates' level of problem solving appraisal and utilization of motivated strategies for learning in terms of class level?

As the result of the simple correlation analysis, it has been found that there is a significant relationship between the problem solving appraisal and the utilization of motivated strategies for learning of teacher candidates of all the class levels, except the first class. While there has not been a significant relationship between the problem solving appraisal and the utilization of motivated strategies for learning of teacher candidates of first class $(r=-.254, p>.05)$, there has been a negative sided, moderate and significant relationship between the problem solving appraisal and the utilization of motivated strategies for learning of the teacher candidates of second class $(r=-.296, p<.01)$, third class $(r=-.280, p$ $<.01)$ and fourth class $(\mathrm{r}=-.232, \mathrm{p}<.05)$. The findings related to the fourth sub-problem are given in Table 5 .

Table 5. The relationship between teacher candidates' problem solving appraisal and their utilization of motivated strategies for learning in terms of class level

\begin{tabular}{|c|c|c|c|c|c|}
\hline \multirow[t]{2}{*}{ Class level } & & \multicolumn{4}{|c|}{ Problem solving appraisal } \\
\hline & & & $\mathrm{r}$ & $\mathrm{N}$ & $\mathrm{p}$ \\
\hline \multirow{3}{*}{1} & Utilization of & $\mathrm{r}$ & -.254 & \multirow{3}{*}{51} & \\
\hline & motivated & $\mathrm{N}$ & & & \\
\hline & strategies & $\mathrm{p}$ & & & .072 \\
\hline \multirow{3}{*}{2} & Utilization of & $\mathrm{r}$ & $-.296 * *$ & \multirow{3}{*}{84} & \\
\hline & motivated & $\mathrm{N}$ & & & \\
\hline & strategies & $\mathrm{p}$ & & & .006 \\
\hline \multirow{3}{*}{3} & Utilization of & $\mathrm{r}$ & $-.280 * *$ & \multirow{3}{*}{180} & \\
\hline & motivated & $\mathrm{N}$ & & & \\
\hline & strategies & $\mathrm{p}$ & & & .000 \\
\hline \multirow{3}{*}{4} & Utilization of & $\mathrm{r}$ & $-.232 *$ & \multirow{3}{*}{101} & \\
\hline & motivated & $\mathrm{N}$ & & & \\
\hline & strategies & $\mathrm{p}$ & & & .019 \\
\hline
\end{tabular}

$5^{\text {th }}$ Sub-problem: Does teacher candidates' level of problem solving appraisal predict their utilization of motivated strategies for learning?

As the result of the simple regression analysis, it has been found that teacher candidates' problem solving appraisal predicts their utilization of motivated strategies for learning $\left(\mathrm{F}_{(1-414)}=30.518, \mathrm{p}<.05\right)$. The findings related to the fifth sub-problem are given in Table 6. 
Table 6 . The prediction of teacher candidates' utilization of motivated strategies by their problem solving appraisal

\begin{tabular}{lccccc}
\hline & Sum of squares & Df & Mean of squares & F & P \\
\hline Regression & 16790.765 & 1 & 16790.765 & & \\
Constant & 227776.818 & 414 & 550.184 & 30.518 & .000 \\
Total & 244566.940 & 415 & & & \\
\hline
\end{tabular}

$\mathrm{R}=.262 ; \mathrm{R}^{2}=.069 ;$ Adjusted $\mathrm{R}^{2}=.066$

$6^{\text {th }}$ Sub-problem: Do teacher candidates' level of problem solving appraisal and other various variables (gender, department, class level) have a common effect on their utilization of motivated strategies for learning?

As the result of the two-way anova, it has been found that teacher candidates' problem solving appraisal and various variables (gender, department, class level) do not have a common effect on their utilization of motivated strategies for learning $(\mathrm{p}>.05)$. The findings related to the sixth sub-problem are given in Table 7.

Table 7. Analysis on the common effect of variables on the utilization of motivated strategies for learning

\begin{tabular}{|c|c|c|c|c|c|c|}
\hline Variables & $\begin{array}{l}\text { Sum of } \\
\text { squares }\end{array}$ & Df & $\begin{array}{l}\text { Mean of } \\
\text { squares }\end{array}$ & $\mathbf{F}$ & $\mathbf{p}$ & $\begin{array}{c}\text { Effect } \\
\text { size }\end{array}$ \\
\hline $\begin{array}{l}\text { Gender* Problem solving appraisal } \\
\text { Error }\end{array}$ & $\begin{array}{c}286.471 \\
223652.749\end{array}$ & $\begin{array}{c}1 \\
411 \\
\end{array}$ & $\begin{array}{l}286.471 \\
544.167\end{array}$ & 0.526 & .469 & - \\
\hline $\begin{array}{lll}\text { Department* } & \text { Problem } & \text { solving } \\
\text { appraisal } & & \\
\text { Error } & & \\
\end{array}$ & $\begin{array}{c}2812.747 \\
214815.684\end{array}$ & $\begin{array}{r}5 \\
403 \\
\end{array}$ & $\begin{array}{l}562.549 \\
533.041 \\
\end{array}$ & 1.055 & .385 & - \\
\hline $\begin{array}{l}\text { Class level*Problem solving } \\
\text { appraisal } \\
\text { Error } \\
\end{array}$ & $\begin{array}{c}1046.134 \\
219756.267\end{array}$ & $\begin{array}{c}3 \\
407\end{array}$ & $\begin{array}{l}348.711 \\
539.942\end{array}$ & .646 & .586 & - \\
\hline Total & 242880.901 & 414 & & & & \\
\hline
\end{tabular}

\section{Results and Discussion}

This study has investigated the relationship between teacher candidates' problem solving appraisal and their utilization of motivated strategies for learning. The first sub-problem of the study has investigated whether there is a significant relationship between teacher candidates' problem solving appraisal and their utilization of motivated strategies for learning. The result for the sub-problem has shown that there is a negative-sided and a significant relationship. This result has also shown that this relationship is not very strong at all. According to this result, it can be said that as teacher candidates' problem solving appraisal increase, their utilization of motivated strategies for learning decrease. However, it must be considered that the power of this relationship is insufficient. Therefore, it can be suggested that as teacher candidates' problem solving appraisal increase, their self-confidence might have been increased and for this reason their tendency to utilize motivated strategies for learning might have been decreased.

The second sub-problem of the study has investigated whether there is a significant relationship between teacher candidates' problem solving appraisal and their utilization of motivated strategies for learning in terms of gender. The result has shown that there is a significant and a negative-sided relationship between teacher candidates' problem solving appraisal and their utilization of motivated strategies for both genders. Because problem solving perception is a learned structure and for this reason it is appropriate for change (Heppner, Witty \& Dixon, 2004), considering teacher candidates' problem solving appraisal and their utilization of motivated strategies for learning are significantly and negatively related for both genders, it can be suggested that as teacher candidates' problem solving appraisal increases for both genders, their self-confidence might have been increased and therefore their tendency to utilize motivated strategies for learning might have been decreased.

The third sub-problem of the study has investigated whether there is a significant relationship between teacher candidates' problem solving appraisal and their utilization of motivated strategies for learning in terms of their departments. The result has shown that there is not a significant relationship between teacher candidates' problem solving appraisal and the utilization of motivated strategies for learning of the departments Elementary Science Education and Early Childhood Education. On the contrary, it has been found that there is a significant and a negative-sided relationship between teacher candidates' problem solving appraisal and the utilization of motivated strategies for learning for the departments Social Studies Education, Primary Education, Turkish Language Education and Elementary Math Education. Considering the self-regulating individuals use more strategies (Zimmerman, 1990; as cited in Bozpolat, 2016) and primary self-regulative processes are related to effective problem solving process (Çelik-Ercoşkun \& Köse, 2014) and also self-confidence about own skills is related to more effective problem solving (Bloom \& Broder, 1950; as cited in Heppner, 1978), the finding that there is a negative-sided and a significant relationship between teacher candidates' problem solving appraisal and the utilization of motivated strategies for 
learning for the departments except Elementary Science Education and Early Childhood Education can be interpreted as following. As teacher candidates' appraisal of their problem solving increase, their tendency to utilize motivated strategies for learning might have been decreased for the departments except Elementary Science Education and Early Childhood Education because of their probably unrealist appraisal of their own problem solving skills.

The fourth sub-problem of the study has investigated whether there is significant relationship between teacher candidates' problem solving appraisal and their utilization of motivated strategies for learning in terms of class level. The result has shown that there is not a significant relationship between first class students' problem solving appraisal and the utilization of motivated strategies for learning. Besides that, there is a significant and a negative-sided relationship between second, third and fourth class students' problem solving appraisal and their utilization of motivated strategies for learning. Considering that for students, when there exists a fear of being unsuccessful, there exists also a tendency to avoid himself/herself from that task; but if he/she believes that he/she can overcome that task, he/she can resist against the adversities (Kahraman \& Sungur, 2011), the finding can be interpreted as following. As the problem solving appraisal of the second, third and fourth class students increase, their tendency to utilize motivated strategies for learning decrease, because their self-confidence about their skills against possible difficulties might be providing the resistance for struggling for the potential fear of being unsuccessful.

The fifth sub-problem of the study has investigated whether teacher candidates' utilization of motivated strategies for learning is predicted by their problem solving appraisal and the result has shown that problem solving appraisal of teacher candidates predicts their utilization of motivated strategies for learning. This finding is a support for the previous findings indicating that the individuals confident about their problem solving skills are more competent at problem solving (Bloom \& Broder, 1950; as cited in Heppner, 1978) and the successful problem solvers use more strategies for controlling their own behaviors (Heffernan \& Richards, 1981; as cited in Heppner \& Petersen, 1982). It is determinative whether an individual has a positive or negative perception about his/her problem solving skills because a negative self-concept originating from a negative mood might be effecting the individual's attention, cognition and learning considerably (Pintrich, 1999). As known, the approach of manifesting the possible solutions in a problem solving situation provides both finding as many as solution alternatives, and also the increase of the quality of the solutions, accompanying also providing the possible best solution (D'Zurilla \& Nezu, 1980). Therefore, as the finding supports, it is supposed that whether problem solving appraisal is positive or negative determines whether teacher candidates utilize motivated strategies for learning.

The sixth sub-problem of the study has investigated whether problem solving appraisal and various variables (gender, department, class level) have a common effect on the utilization of motivated strategies for learning. The result has shown that problem solving appraisal and various variables (gender, department, class level) do not have a common effect on the utilization of motivated strategies for learning.

In summary, it has been investigated whether there is a significant relationship between teacher candidates' problem solving appraisal and their utilization of motivated strategies for learning and as a general result, it has been found that there is a negative-sided and a significant relationship between problem solving appraisal and the utilization of motivated strategies for learning, considering that the degree of the negative-sided relationship is limited.

\section{References}

Baker, S. R. (2003). A prospective longitudinal investigation of social problem-solving appraisals on adjustment to university, stress, health, and academic motivation and performance, Personality and Individual Differences, 35(3), 569-591. https://doi.org/10.1016/S0191-8869(02)00220-9

Bozpolat, E. (2016). Investigation of the self-regulated learning strategies of students from the faculty of education using ordinal logistic regression analysis, Educational Sciences: Theory \& Practice, 16(1), 301-318.

Brown, G. T. L., Peterson, E. R., \& Yao, E. S. (2016). Student conceptions of feedback: Impact on self-regulation, self-efficacy, and academic achievement, British Journal of Educational Psychology, 86, 606-629. https://doi.org/10.1111/bjep.12126

Bruso, J. L., \& Stefaniak, J. E. (2016). The use of self-regulated learning measure questionnaires as a predictor of academic success, Tech Trends, 60, 577-584. https://doi.org/10.1007/s11528-016-0096-6

Butler, D. L. (1995). Feedback and self-regulated learning: A theoretical synthesis, Review of Educational Research, 65(3), 245-281. https://doi.org/10.3102/00346543065003245

Büyüköztürk, Ş. (2011). Data analysis for social sciences. Ankara: Pegem Akademi.

Büyüköztürk, Ş., Kılıç-Çakmak, E., Akgün, Ö. E., Karadeniz, Ş., \& Demirel, F. (2011). Scientific research methods. Ankara: Pegem Akademi. 
Can, A. (2013). Quantitative data analysis with SPSS. Ankara: Pegem Akademi.

Çelik-Ercoşkun, N., \& Köse, E. (2014). The examination of primary education teacher candidates' self-regulation and problem solving skills, International Online Journal of Educational Sciences, 6(2), 413-428. https://doi.org/10.15345/iojes.2014.02.014

Covington, M. V. (1998). The will to learn. Cambridge University Press.

D'Zurilla, T. J., \& Goldfried, M. R. (1971). Problem solving and behavior modification, Journal of Abnormal Psychology, 78(1), 107-126. https://doi.org/10.1037/h0031360

D'Zurilla, T. J., \& Nezu, A. (1980). A study of the generation-of-alternatives process in social problem solving, Cognitive Therapy and Research, 4(1), 67-72. https://doi.org/10.1007/BF01173355

Dembo, M. H., \& Eaton, M. J. (1997). School learning and motivation. In G. Phye (Ed.), "Handbook of Academic Learning”. Academic Press. https://doi.org/10.1016/B978-012554255-5/50004-1

Engelschalk, T., Steuer, G., \& Dresel, M. (2016). Effectiveness of motivational regulation: Dependence on specific motivational problems, Learning and Individual Differences, 52, $72-78$.

https://doi.org/10.1016/j.lindif.2016.10.011

Gelbal, S. (1991). Problem solving, Hacettepe Üniversitesi Ĕ̈itim Fakültesi Dergisi, 6, 167-173.

Heppner, P. P., \& Petersen, C. H. (1982). The development and implications of a personal problem-solving inventory, Journal of Counseling Psychology, 29(1), 66-75. https://doi.org/10.1037/0022-0167.29.1.66

Heppner, P. P., Reeder, B. L., \& Larson, L. M. (1983). Cognitive variables associated with personal problem-solving appraisal: Implications for counseling, Journal of Counseling Psychology, 30(4), 537-545. https://doi.org/10.1037/0022-0167.30.4.537

Heppner, P. P., Witty, T. E., \& Dixon, W. A. (2004). Problem-solving appraisal and human adjustment: a review of 20 years of research using the Problem Solving Inventory, The Counseling Psychologist, 32(3), 344-428. https://doi.org/10.1177/0011000003262793

Heppner, P. P. (1978). A review of the problem-solving literature and its relationship to the counseling process, Journal of Counseling Psychology, 25(5), 366-375. https://doi.org/10.1037/0022-0167.25.5.366

Kahraman, N., \& Sungur, S. (2011). The contribution of motivational beliefs to students' metacognitive strategy use, Ĕ̈itim ve Bilim, 36 (160), 3-10.

Karasar, N. (2010). The scientific research method. Ankara: Nobel Yayın Dağıtım.

Kizilcec, R. F., Perez-Sanagustin, M., \& Maldonado, J. J. (2017). Self-regulated learning strategies predict learner behavior and goal attainment in Massive Open Online Courses, Computers \& Education, 104, 18-33. https://doi.org/10.1016/j.compedu.2016.10.001

Littlejohn, A., Hood, N., Milligan, C., \& Mustain, P. (2016). Learning in MOOCs: Motivations and self-regulated learning in MOOCs, Internet and Higher Education, 29, 40-48. https://doi.org/10.1016/j.iheduc.2015.12.003

Ocak, G., \& Eğmir, E. (2014). Investigation of pre-service teachers' problem solving skills in terms of different variables, Asya Ögretim Dergisi, 2(1), 27-45.

Pintrich, P. R. (1999). Understanding interference and inhibition processes from a motivational and self-regulated learning perspective: Comments on Dempster and Corkill, Educational Psychology Review, 11(2), 105-115. https://doi.org/10.1023/A:1022020308002

Pintrich, P. R. (2004). A conceptual framework for assessing motivation and self-regulated learning in college students, Educational Psychology Review, 16(4), 385-407. https://doi.org/10.1007/s10648-004-0006-x

Pintrich, P. R., Smith, D. A. F., Garcia, T., \& McKeachie, W. J. (1993). Reliability and predictive validity of the Motivated Strategies for Learning Questionnaire (MSLQ), Educational and Psychological Measurement, 53, 801-813. https://doi.org/10.1177/0013164493053003024

Selçuk, Z. (2012). Educational psychology. Ankara: Nobel Akademik Yayıncılık.

Senler, B. (2011). Pre-service science teachers' self-efficacy in relation to personality traits and academic self-regulation. Unpublished doctoral thesis, Orta Doğu Teknik Üniversitesi Sosyal Bilimler Enstitüsü.

Sungur, S. (2004). The implementation of problem based learning in high school biology courses. Unpublished doctoral thesis, Orta Doğu Teknik Üniversitesi.

Zimmerman, B. J., \& Martinez-Pons, M. (1992). Perceptions of efficacy and strategy use in the self-regulation of 
learning. In D.H. Schunk \& J.L. Meece (Eds.) "Students perceptions in the classroom" Lawrence Erlbaum Associates, Inc.

Zimmerman, B. J., \& Risemberg, R. (1997). Self-regulatory dimensions of academic learning and motivation. In G.
Phye
(Ed.).
"Handbook
of
Academic
Learning"
Academic
Press.

https://doi.org/10.1016/B978-012554255-5/50005-3

\section{Copyrights}

Copyright for this article is retained by the author(s), with first publication rights granted to the journal.

This is an open-access article distributed under the terms and conditions of the Creative Commons Attribution license which permits unrestricted use, distribution, and reproduction in any medium, provided the original work is properly cited. 